\title{
PENGARUH PEMBERIAN Nigella sativa TERHADAP KADAR IGE, IL-6 PLASMA SERTA SKOR ASTHMA CONTROL TEST PADA ANAK ASMA RINGAN DAN SEDANG
}

\author{
Fadilah Mutaqin $^{\star 凶}$, Wisnu Barlianto**, Sanarto Santoso ${ }^{* \star *}$ \\ Abstrak
}

Asma adalah penyakit saluran respiratori karena inflamasi kronis yang mengakibatkan obstruksi dan hiperreaktivitas saluran respiratori. Patogenesis asma diperankan oleh keseimbangan Th1 dan Th2 yang menstimulasi produksi IgE yang ikatanya dengan sel mast dapat merangsang mediator inflamasi. Selain itu, IL-6 yang diproduksi oleh Th17 juga berperan pada asma. Nigella sativa terbukti dapat menurunkan Th17 dan dapat memperbaiki nilai kontrol asma. Tuuan penelitian ini adalah untuk membuktikan bahwa N. sativa dapat mempengaruhi kadar IgE dan IL-6 plasma serta perbaikan skor Asthma Control Test (ACT) pada anak dengan asma ringan dan sedang. Penelitian ini berjenis eksperimental, clinical trial, pre-post control study. Populasi penelitian yaitu penderita asma ringan dan sedang yang dinilai berdasarkan kriteria GINA 2016. Subjek dibagi menjadi 4 kelompok yaitu kelompok A (asma ringan, mendapat terapi short acting beta agonis, kortikosteroid inhalasi dosis rendah dan N. sativa) dan kelompok B (asma sedang, mendapat terapi long acting beta agonis, kortikosteroid inhalasi dosis rendah dan N. sativa), kelompok C (kontrol) (asma ringan, hanya mendapat terapi short acting beta agonis, kortikosteroid inhalasi dosis rendah) dan kelompok D (asma sedang, hanya mendapat terapi long acting beta agonis, kortikosteroid inhalasi dosis rendah). Pada pasien diuji kadar IgE, IL-6 dan skor ACT sebelum dan sesudah perlakuan yang diberikan perlakuan selama 8 minggu. Data dianalisis secara statistik dengan aplikasi SPSS ver 18. Didapatkan kadar lgE pada kelompok asma sedang $(B, D)$ lebih tinggi dibandingkan dengan asma ringan $(A, C)$ dan didapatkan penurunan rerata kadar IgE total pada semua kelompok meskipun nilainya tidak berbeda bermakna ( $\mathrm{A}: \mathrm{p}=$ $0,482, B: p=0,277 ; C: p=0,18 ; D: p=0,655$ ). Didapatkan penurunan rerata kadar IL-6 pada semua kelompok meskipun nilainya tidak berbeda bermakna (A: $p=0,123 ; \mathrm{B}: p=0,338 ; \mathrm{C}: p=0,848 ; \mathrm{D}: \mathrm{p}=$ $0,564)$. Terdapat perbedaan bermakna skor ACT pada kelompok $A(p=0,016)$ maupun kelompok $C$ (kontrol) $(p=003)$ dibandingkan dengan sebelum perlakuan. Tidak didapatkan hubungan antara kadar lgE dengan skor ACT maupun IL-6 dengan skor ACT setelah diberikan $N$. sativa $(p>0,05)$. N. sativa dapat menurunkan kadar IL-6 dan IgE plasma pada anak dengan asma ringan dan sedang serta perbaikan skor ACT pada anak dengan asma sedang meskipun nilainya tidak berbeda bermakna, tetapi sangat bermakna pada asma ringan. Tidak terdapat hubungan antara penurunan IgE dan IL-6 plasma dengan peningkatan skor ACT setelah pemberian $N$. sativa pada anak asma ringan dan sedang.

Kata kunci: asthma control test, IgE, IL-6, Nigella sativa.

\section{EFFECT OF Nigella sativa ON PLASMA IgE, IL-6 LEVELS AND ACT SCORE IMPROVEMENT ON CHILDREN WITH MILD AND MODERATE ASTHMA}

\begin{abstract}
Asthma is a respiratory disease with a basis of chronic inflammation which results in varying degrees of obstruction and hyperreactivity of the respiratory tract. The pathogenesis of asthma is played by the balance of Th1 and Th2 which stimulates the production of $\mathrm{gEE}$ whose binding with mast cells can stimulate inflammatory mediators. In addition IL-6 produced by Th17 also plays a role in asthma. Nigella sativa has been proved to reduce Th17 levels and improve the value of asthma control. This research is to prove that N. sativa can affect plasma IgE and IL-6 levels and improve Asthma Control Test (ACT) scores in children with mild and moderate asthma. This research is experimental, clinical trial, pre-post control study. The study population was mild and moderate asthma sufferers assessed based on the 2016 GINA criteria. Subjects were divided into 4 groups, group A (mild asthma, receiving short-acting beta agonist therapy, lowdose inhaled corticosteroids and N. Sativa) and group B (moderate asthma, received long-acting beta agonist therapy, low-dose inhaled corticosteroids and N. Sativa), group C (control) (mild asthma, only received short-acting beta agonist therapy, low-dose inhaled corticosteroid) and group D (moderate asthma, only received therapy long acting beta agonist, low dose inhaled corticosteroid). Previously, the patients were examined for IgE, IL-6 and ACT scores. Then the patients were given treatment for 8 weeks, then reassessed levels of $\mathrm{IgE}$, IL-6 and ACT scores after treatment. Data were statistically analyzed using SPSS 18. Obtained IgE levels in the moderate asthma group compared with mild asthma and obtained a mean decrease in total IgE levels in all groups even though the value was not statistically significant (A: $p=0.482$; $B: p=0.277 ; C: p=0.18 ; D: p=0.655$ ). The mean decrease in IL-6 levels in all groups was obtained even
\end{abstract}


though the value was not significantly different $(A: p=0.123 ; B: p=0.338 ; C: p=0.848 ; D: p=0.564)$. There was a significant difference in ACT scores in the mild asthma group after treatment in the group given $N$. sativa and the control group (A: $p=0.016$; $\mathrm{:} p=003$ ) compared to before treatment. There was no relationship between IgE levels with ACT scores or IL-6 with ACT scores after being given $N$. sativa ( $p$ > 0.05). The administration of $N$. sativa can reduce plasma IL-6 and IgE levels in children with mild and moderate asthma and improve Asthma Control Test scores in children with moderate asthma even though the value is not significantly different, but it is very meaningful to increase ACT scores in mild asthma and there was no relationship between decreased IgE and IL-6 plasma with an increase in the ACT score after administration of $N$. sativa in mild and moderate asthma children.

Keywords: asthma control test, IgE, IL-6, Nigella sativa.

* Program Magister (S2) IImu Biomedik, Fakultas Kedokteran, Universitas Brawijaya

** Departemen ilmu Kesehatan Anak, Fakultas Kedokteran, Universitas Brawijaya

*** Departemen Mikrobiologi klinik, Fakultas Kedokteran, Universitas Brawijaya

E-mail: fadilahmutaqin25888@gmail.com

\section{Pendahuluan}

Asma adalah mengi dan atau batuk yang timbul secara episodik dan atau kronis, cenderung pada malam atau dini hari, musiman, ada faktor pencetus, dan bersifat reversible baik secara spontan maupun dengan pengobatan, serta adanya riwayat asma atau atopi lain pada pasien atau keluarganya, sementara penyebab yang lain sudah disingkirkan. Prevalensi asma di seluruh dunia adalah sebesar $8-10 \%$ pada anak dan 3-5\% pada dewasa. ${ }^{1}$ Di Indonesia prevalensi asma pada anak sekitar 2-16\% pada anak usia sekolah dasar, sedangkan di Jawa Timur, pada tahun 2013 tercatat prevalensi asma sebesar 3,9\% pada usia 0-14 tahun. $^{2}$

Asma merupakan penyakit saluran nafas dengan ciri terjadi inflamasi saluran nafas kronis, produksi mukus, hiperresponsif dan remodeling saluran nafas. ${ }^{1}$ Imunoglobulin $\mathrm{E}$ mempunyai peran sentral dalam patofisiologi peradangan pada alergi dan asma. Interaksi alergen pada limfosit $B$ dengan limfosit $T$ spesifik akan menyebabkan limfosit $B$ memproduksi $\operatorname{lgE}$ spesifik allergen. ${ }^{3} \operatorname{lgE}$ spesifik akan berikatan dengan sel-sel yang mempunyai reseptor IgE seperti sel mast, basofil, eosinofil, makrofag dan platelet yang dapat menginduksi sinyal sel dan merangsang degranulasi sel mastosit, sehingga mediator inflamasi akan dilepaskan. ${ }^{4}$

Paradigma keseimbangan Th2 dan Th1 dalam mengendalikan asma saat ini mulai berubah oleh sel $\mathrm{T}$ helper subset ketiga yaitu Th17. ${ }^{5}$ Pada penelitian yang dilakukan oleh Barlianto, terbukti bahwa tingkat Th17 dapat mempengaruhi derajat serangan asma. ${ }^{6}$ Salah satu faktor yang dapat mempengaruhi sel Th0 menjadi Th17 yaitu interleukin- $6 .^{7}$

Nigella sativa (jinten hitam) merupakan salah satu tanaman yang bermanfaat untuk pengobatan asma. Barlianto menyatakan bahwa pemberian $N$. sativa terbukti dapat menurunkan tingkat Th17 dan meningkatkan Treg. ${ }^{6}$ Pemberian terapi tambahan dengan $N$. sativa dapat memperbaiki nilai kontrol asma. ACT mempunyai akurasi yang lebih baik untuk penilaian kontrol asma. ${ }^{8}$

Sebagaimana yang telah diketahui bahwa N. Sativa mampu menurunkan tingkat Th17 dan Treg sehingga diharapkan juga mampu menurunkan kadar IL-6 dan IgE pada asma. Tujuan penelitian ini untuk membuktikan bahwa pemberian $N$. Sativa dapat mempengaruhi kadar IgE dan IL-6 plasma serta perbaikan skor Asthma Control Test (ACT) pada anak dengan asma ringan dan sedang. 


\section{Bahan dan Metode}

\section{Desain dan Populasi Penelitian}

Penelitian ini merupakan penelitian eksperimental, clinical trial, pre-post control study. Anak yang terdiagnosis asma ringan dan sedang berdasarkan kriteria GINA 2016 dengan usia 4-14 tahun yang merupakan pasien rawat jalan di Poli Alergi Imunologi dan Respirologi Rumah Sakit Saiful Anwar Malang. Subjek dibagi menjadi 4 kelompok, yaitu kelompok $A$ (asma ringan, mendapat terapi standart short acting beta agonis, kortikosteroid inhalasi dosis rendah dan $N$. sativa) dan kelompok B (asma sedang, mendapat terapi standart long acting beta agonis, kortikosteroid inhalasi dosis rendah dan N. sativa), kelompok kontrol pada kelompok $\mathrm{C}$ (asma ringan, hanya mendapat terapi standart short acting beta agonis, kortikosteroid inhalasi dosis rendah) dan kelompok $D$ (asma sedang, hanya mendapat terapi standart long acting beta agonis dan kortikosteroid inhalasi dosis rendah) tidak diberikan $N$. sativa. Penelitian ini telah mendapatkan persetujuan dari komite etik RS Saiful Anwar dengan nomor surat: 400/127/ K.3/302/2018.

\section{Preparasi Nigella sativa}

$N$. sativa (jinten hitam) yang digunakan minyak jinten hitam dalam kapsul lunak 500 mg (Minyak Habbatussauda MADINAH, Indonesia, POM TR.123 329 761), diberikan dengan dosis $15-30 \mathrm{mg} / \mathrm{kgBB} / \mathrm{hari}$.

\section{Pengukuran Kadar lgE dan IL-6}

Kadar IgE yang dinilai adalah IgE total pada plasma dengan satuan IU/ml. Kadar IL-6 yang dinilai adalah kadar IL-6 pada plasma yang diukur dengan menggunakan metode flowcytometri.

\section{Penilaian Asma Control Test (ACT)}

Penilaian tingkat kontrol asma dilakukan dengan ACT yang juga biasa digunakan oleh penyedia layanan kesehatan di Indonesia. ACT terdiri dari lima pertanyaan dalam skala total 5-25 dengan masing-masing skala dari 1 -5 . Kontrol penuh ditentukan sebagai total skor ACT dari 25.

\section{Analisis Data}

Analisis data statistik dilakukan dengan menggunakan SPSS versi 18.0 dengan tingkat signifikansi dari $p<0,05$. Normalitas dan homogenitas data diuji dengan uji Shapiro-Wilk dan uji Levene, diikuti oleh paired and unpaired t-test untuk analisis komparatif. Korelasi Pearson digunakan untuk mengukur hubungan antara dua variabel.

\section{Hasil}

Penelitian ini mendapatkan sampel sebanyak 28 anak yang terdiagnosa asma ringan dan asma sedang yang dibagi menjadi 4 kelompok yang berjumlah 7 anak tiap kelompok yaitu kelompok A, B, C, D. Kelompok A (asma ringan, mendapat terapi short acting beta agonis, kortikosteroid inhalasi dosis rendah dan $N$. sativa), kelompok B (asma sedang, mendapat terapi long acting beta agonis, kortikosteroid inhalasi dosis rendah dan $N$. sativa), kelompok $C$ (kontrol) (asma ringan, hanya mendapat terapi short acting beta agonis, kortikosteroid inhalasi dosis rendah) dan kelompok D (asma sedang, hanya mendapat terapi long acting beta agonis, kortikosteroid inhalasi dosis rendah). Distribusi jenis kelamin laki-laki dan perempuan pada keempat kelompok dalam jumlah yang hampir sama dengan rentang usia rata-rata dari responden yaitu 7-9 tahun (Tabel 1).

Kadar IgE Sebelum dan Setelah Pemberian N. sativa

Perbandingan kadar IgE sebelum dan setelah perlakuan pada masing-masing kelompok dianalisis menggunakan uji Mann Whitney. 
Berdasarkan uji asumsi normalitas tidak terpenuhi (nilai $p<0,05$ ) dan asumsi homogenitas juga tidak terpenuhi (nilai $p<$ 0,05 ), sehingga uji yang digunakan adalah uji Mann Whitney. Hasil pengujian dapat dilihat pada Tabel 2.

Hasil analisis kadar IgE sebelum dan sesudah perlakuan dengan menggunakan uji Mann Whitney, dapat disimpulkan bahwa tidak ada perbedaan yang bermakna karena nilai $p>0,05$, meskipun dari rerata nilai $\lg E$ didapatkan penurunan setelah diberikan $N$. sativa.

\section{Perbedaan Kadar IL-6 Sebelum dan Setelah Pemberian N. sativa}

Perbandingan kadar IL-6 sebelum dan setelah pemberian $N$. sativa pada masingmasing kelompok dianalisis menggunakan uji Mann Whitney. Berdasarkan Tabel 3 asumsi normalitas tidak terpenuhi (nilai $p<0,05$ ) dan
Tabel 4 asumsi homogenitas juga tidak terpenuhi (nilai $p<0,05$ ), sehingga uji yang digunakan adalah uji Mann Whitney. Hasil analisis kadar IL-6 sebelum dan sesudah pemberian $N$. sativa dengan menggunakan uji Mann Whitney, dapat disimpulkan bahwa tidak ada perbedaan yang bermakna karena nilai $p>0,05$ meskipun dari rerata nilai IL-6 didapatkan penurunan setelah diberikan $N$. sativa.

Perbedaan Skor ACT Sebelum dan Setelah Pemberian N. sativa

Analisis perbandingan skor ACT sebelum dan setelah pemberian $N$. sativa pada masing-masing kelompok menggunakan uji paired $T$ (Tabel 4). Hasil menunjukkan peningkatan yang signifikan dari skor ACT sebelum dan setelah perlakuan pada kelompok asma ringan ( $A$ dan $C)(p<0,05)$.

Tabel 1. Karakteristik subjek tiap kelompok

\begin{tabular}{ccccc}
\hline Kriteria & $\begin{array}{c}\text { Kelompok A } \\
(\mathrm{n}=7)\end{array}$ & $\begin{array}{c}\text { Kelompok B } \\
(\mathrm{n}=7)\end{array}$ & $\begin{array}{c}\text { Kelompok C } \\
(\mathrm{n}=7)\end{array}$ & $\begin{array}{c}\text { Kelompok D } \\
(\mathrm{n}=7)\end{array}$ \\
\hline Jenis kelamin & & & & \\
Perempuan & $4(4 / 7)$ & $3(3 / 7)$ & $4(4 / 7)$ & $4(4 / 7)$ \\
Laki-laki & $3(3 / 7)$ & $4(4 / 7)$ & $3(3 / 7)$ & $3(3 / 7)$ \\
Rerata usia (tahun) & $7,6 \pm 4,2$ & $9,8 \pm 5,4$ & $7,07 \pm 6,5$ & $9,5 \pm 5,8$ \\
\hline
\end{tabular}

Tabel 2. Perbedaan kadar IgE sebelum dan setelah pemberian N. sativa

\begin{tabular}{ccccc}
\hline \multirow{2}{*}{ Kelompok } & \multicolumn{2}{c}{ Kadar $\operatorname{lgE}(\mathrm{IU} / \mathrm{ml})$} & \multirow{2}{*}{ Selisih } & \multirow{2}{*}{ Nilai $\mathrm{p}$} \\
\cline { 2 - 3 } & Sebelum & Setelah & & \\
\hline A & $560,73 \pm 239,86$ & $356,76 \pm 80,12$ & 203,76 & 0,482 \\
B & $724,96 \pm 422,56$ & $415,20 \pm 302,08$ & 309,76 & 0,277 \\
C & $509,75 \pm 171,44$ & $457,47 \pm 141,60$ & 52,28 & 0,180 \\
D & $1055,63 \pm 478,75$ & $950,29 \pm 348,92$ & 105,34 & 0,655 \\
\hline
\end{tabular}

Keterangan: Signifikan jika nilai $p<0,05$ 
Tabel 3. Perbedaan kadar IL-6 sebelum dan setelah pemberian N. sativa

\begin{tabular}{ccccc}
\hline \multirow{2}{*}{ Kelompok } & \multicolumn{2}{c}{ Kadar IL-6 } & \multirow{2}{*}{ Selisih } & \multirow{2}{*}{ Sig Uji t } \\
\cline { 2 - 3 } & Sebelum & Setelah & & \\
\hline A & $33,41 \pm 1,61$ & $32,31 \pm 1,14$ & 1,1 & 0,123 \\
B & $39.89 \pm 5,93$ & $37.48 \pm 4,74$ & 2,41 & 0,338 \\
C & $33,80 \pm 1,85$ & $33,44 \pm 1,68$ & 0,36 & 0,848 \\
D & $40,95 \pm 4,88$ & $40,28 \pm 4,70$ & 0,67 & 0,564 \\
\hline
\end{tabular}

Keterangan: Signifikan jika nilai $p<0,05$

Tabel 4. Perbedaan skor ACT sebelum dan setelah pemberian N. sativa

\begin{tabular}{ccccc}
\hline \multirow{2}{*}{ Kelompok } & \multicolumn{2}{c}{ Skor ACT } & \multirow{2}{*}{ Selisih } & \multirow{2}{*}{ Sig Uji t } \\
\cline { 2 - 3 } & Sebelum & Setelah & & \\
\hline A & $18 \pm 0,82$ & $21 \pm 0,82$ & 3 & 0,016 \\
B & $15,14 \pm 2,91$ & $19,42 \pm 2,30$ & 4,28 & 0,253 \\
C & $17,85 \pm 1,21$ & $20,71 \pm 0,76$ & 2,85 & 0,003 \\
D & $17,28 \pm 1,25$ & $18,57 \pm 0,97$ & 1,28 & 0,406 \\
\hline
\end{tabular}

Keterangan: Signifikan jika nilai $p<0,05$

Hubungan antara Kadar IgE dan IL-6 dengan Skor ACT

Berdasarkan Tabel 5 diketahui bahwa terdapat korelasi yang signifikan antara kadar IgE dan skor ACT pada kelompok $A$ ( $p=$ $0,004)$ dan kelompok $C$ sebelum perlakuan ( $p$ $=0,007$ ), dengan koefisien korelasi negatif yang kuat $(r=-0,911$ dan $r=-0,889)$ yang artinya semakin tinggi kadar lgE maka semakin rendah skor ACT dan sebaliknya.
Pada Tabel 6 ditunjukkan bahwa pada semua kelompok didapatkan nilai korelasi antara kadar IL-6 dan skor ACT sebelum dan setelah perlakuan lebih besar dari 0,05 (kelompok $A p=0,055, p=0,949$; kelompok $\mathrm{B} p=0,186, p=691$; kelompok $\mathrm{C} p=0,066$, $p=0,341$; kelompok $D p=0,621, p=0,858$ ) yang mempunyai arti bahwa tidak ada hubungan antara kadar IL-6 plasma dan skor ACT.

Tabel 5. Uji korelasi kadar lgE dengan skor ACT

\begin{tabular}{lll}
\hline \multicolumn{1}{c}{ Kelompok } & Nilai p & Korelasi (r) \\
\hline A Sebelum & $0,004^{*}$ & $-0,911$ \\
$\begin{array}{l}\text { Setelah } \\
\text { B Sebelum }\end{array}$ & 0,973 & $-0,016$ \\
Sebelum & 0,102 & $-0,667$ \\
S & 0,085 & $-0,692$ \\
Sebelum & $0,007^{*}$ & $-0,889$ \\
Setelah & 0,879 & $-0,071$ \\
D Sebelum & 0,142 & $-0,615$ \\
$\quad$ Setelah & 0,114 & $-0,650$ \\
\hline
\end{tabular}

Keterangan: Signifikan jika nilai $p<0,05$ 
Tabel 6. Uji korelasi kadar IL-6 dengan skor ACT

\begin{tabular}{lcc}
\hline \multicolumn{1}{c}{ Kelompok } & Nilai $\mathrm{p}$ & Korelasi $(\mathrm{r})$ \\
\hline $\mathrm{A}$ Sebelum & 0,055 & 0,744 \\
$\begin{array}{l}\text { Setelah } \\
\text { B Sebelum }\end{array}$ & 0,949 & $-0,030$ \\
$\quad 0,186$ & $-0,566$ \\
$\quad$ Setelah & 0,691 & $-0,185$ \\
C Sebelum & 0,066 & 0,724 \\
$\quad$ Setelah & 0,341 & $-0,426$ \\
D Sebelum & 0.621 & $-0,229$ \\
$\quad$ Setelah & 0,858 & 0,084 \\
\hline
\end{tabular}

Keterangan: Signifikan jika nilai $p<0,05$

\section{Pembahasan}

Penelitian ini merupakan penelitian eksperimental clinical trial, pre-post control study yang bertujuan untuk mengetahui adanya pengaruh pemberian $N$. sativa terhadap kadar IL-6, IgE, dan skor ACT pada anak asma ringan dan sedang serta hubungan antara kadar IL-6, lgE, dan skor ACT. Penentuan besar subjek menggunakan rumus Federer pada empat kelompok perlakuan dengan hasil perhitungan tiap kelompok memerlukan minimal 6 subjek.

Pada penelitian ini terdapat empat kelompok yang diamati, kelompok $\mathrm{A}$ dan $\mathrm{B}$ yaitu kelompok asma ringan dan asma sedang yang diberikan terapi standar dan $N$. sativa sebagai perlakuan, sedangkan kelompok $C$ dan $D$ yaitu asma ringan dan sedang yang diberikan terapi standar saja sebagai kontrol

Pemberian $N$. sativa bermanfaat sebagai imunomodulator, selain itu thymoquinone sebagai zat utama dalam $N$. sativa juga memiliki efek antialergi dan antiasma serta memiliki peran menguntungkan pada pencegahan dan terapi berbagai penyakit alergi. ${ }^{9} N$. sativa memiliki beberapa efek terapi yaitu relaksasi otot trakea dan bronkus, antiinflamasi dan imunomodulator, serta memiliki efek antagonis terhadap reseptor muskarinik dan histamin, efek inhibisi tehadap kanal kalsium dan pembukaan kanal kalium, dan memiliki efek stimulasi $\beta$-adrenoreseptor, yang semua mekanisme tersebut menyebabkan bronkodilatasi otot saluran napas. ${ }^{10}$

Pada kondisi alergi, IgE merupakan molekul yang memediasi reaksi hipersensitivitas tipe 1 (asma alergi, rhinitis alergi, alergi makanan, dermatitis atopi, alergi obat dan alergi sengatan serangga. ${ }^{4}$ Sintesis $\operatorname{lgE}$ spesifik tergantung limfosit CD4+ Th2 yang mensekresikan sitokin seperti IL-4, IL-5, IL-9 dan IL-13. Interleukin-4 merupakan sitokin yang menginduksi limfosit $B$ melakukan switching menjadi isotipe $\operatorname{lgE} .{ }^{11}$ Interaksi alergen pada limfosit $B$ dengan limfosit $T$ spesifik alergen akan menyebabkan limfosit $B$ memproduksi IgE spesifik alergen. Pajanan ulang oleh alergen yang sama akan meningkatkan produksi IgE spesifik. Imunoglobulin $\mathrm{E}$ spesifik akan berikatan dengan sel-sel yang mempunyai reseptor lgE seperti sel mast, basofil, eosinofil, makrofag dan platelet. Bila alergen berikatan dengan sel tersebut maka sel akan teraktivasi dan berdegranulasi mengeluarkan mediator yang berperan pada reaksi inflamasi. ${ }^{3}$ 
Pada penelitian ini, didapatkan kadar IgE pada kelompok asma sedang $(B, D)$ lebih tinggi dibandingkan dengan asma ringan. Setelah dilakukan perlakuan, didapatkan penurunan rerata kadar lgE total pada semua kelompok, meskipun nilainya secara statistik tidak berbeda bermakna. Kelompok asma sedang setelah diberikan $N$. sativa memiliki penurunan kadar IgE terbesar yang diikuti oleh asma ringan yang berikan $N$. sativa dan kelompok kontrol (Tabel 2).

Begitu juga pada penelitian pendahuluan Fattory (2012) menunjukkan bahwa probiotik dan $N$. sativa memiliki peran sebagai imunomodulator, yang ditandai dengan adanya penurunan jumlah IgE antara sebelum dan sesudah fase build up, dan setelah fase rumatan pada kelompok anak asma yang mendapatkan imunoterapi dengan adjuvant probiotik dan atau $N$. sativa dibandingkan dengan yang hanya mendapatkan imunoterapi saja meskipun secara statistik tidak signifikan. ${ }^{12}$ Sedangkan penelitian oleh Sugiono (2013) menunjukan hasil bahwa pemberian imunoterapi kombinasi plus $N$. sativa plus probiotik dapat menurunkan tingkat lgE total dengan signifikan dan memperbaiki gejala klinis yang dibuktikan dengan peningkatan ACT. Tetapi pada pemberian immunoterapi saja juga dapat menurunkan tingkat $\mathrm{lgE}$ dan meningkatkan ACT tetapi nilainya tidak signifikan. Perbedaan ini disebabkan oleh kombinasi imunoterapi, $N$. sativa dan probiotik dapat meningkatkan keberhasilan terapi asma. Mekanisme imunoterapi yaitu dengan mempromosikan sel B untuk memproduksi lgG4 yang dapat menghasilkan IL-10 dan TGF $\beta$. Begitu juga dengan probiotik dan $N$. sativa dapat menginduksi Treg yang memproduksi IL-10.13

Penelitian lain menunjukkan bahwa $N$. sativa dapat menurunkan kadar lgE. Hal ini disebabkan karena $N$. sativa terbukti dapat menurunkan jumlah produksi sel Th2 sehingga dapat menurunkan sitokin IL-4 yang bertanggung jawab terhadap produksi dari sekresi lgE. Selain itu $N$. sativa dapat meningkatkan kadar IFN- $\gamma$ yang dapat menekan produksi sel Th2. ${ }^{14} \mathrm{~N}$. sativa juga menurunkan sel Th2 dengan cara meningkatkan jumlah sel limfosit $\mathrm{T}_{\mathrm{CD}} \mathrm{CD}^{+}$dan menurunkan jumlah sel limfosit T CD4+. ${ }^{+15}$

IL-6 merupakan sitokin yang diproduksi oleh sel inflamasi juga oleh sel epitel paru sebagai respons dari berbagai stimuli seperti allergen, infeksi dan olahraga. ${ }^{16} \quad$ IL-6 mempengaruhi diferensiasi sel Th17 dari sel Th0 CD4+ dengan dibantu oleh IL-21, IL-23 dan TGF- $\beta$ melalui jalur STAT3-RORyt, yang bertanggung jawab terhadap terjadinya netrofilia pada asma alergik. ${ }^{17}$

Sel Th17 menginduksi produksi IL-8 secara in vitro, bersama dengan IL-6, TNF-a, granulocyte-macrophage colony-stimulating factor (GM-CSF), dan antigen terkait pertumbuhan A (GRO- $\alpha$ ) pada sel epitel bronkial dan sel otot polos bronkial manusia dengan mensekresi IL-17A dan IL-17F. Sel Th17 mampu mengaktifkan neutrofil dengan mensekresikan IL-6, TNF- $\alpha$, IL-1 $\beta$, dan IL$17 \mathrm{~A}$, yang bertindak secara sinergis pada produksi dan aktivitas human neutrophil elastase (HNE) dan myeloperoxidase pada otot bronkus. ${ }^{18}$ Penelitian oleh Neveu (2010) dengan populasi asma ringan dan sedang, didapatkan juga hubungan yang terbalik antara kadar IL-6 dan nilai fungsi paru dimana semakin besar kadar IL-6 didapatkan fungsi paru yang semakin kecil. ${ }^{19}$

Penelitian oleh Koshak (2018) menunjukkan bahwa $N$. sativa melalui kandungan thymoquinonenya dapat berfungsi sebagai immunomodulator yang dapat menekan pengeluaran mediator IL-2, IL-6, dan PGE2 dari limfosit T maupun IL-6 dan PGE2 dari monosit. ${ }^{20}$ Penelitian oleh Shahzad (2008) membuktikan bahwa pemberian $N$. sativa secara intraperitoneal pada tikus dapat menghambat respons imun tipe Th2 dengan mencegah infiltrasi sel inflamasi dan lesi patologis pada paru. 
Pemberian $N$. sativa ini juga dapat menurunkan produksi nitrit oksida, serum total IgE, IgG1 dan ekpresi mRNA IL-4, IL-5, IL-6 dan TGF $\beta 1 .{ }^{21}$

Peneltian ini menunjukkan bahwa $N$. sativa dapat menurunkan IL-6. Hal ini disebabkan karena pemberian $N$. sativa dapat menurunkan kadar Th17 dan meningkatkan Treg secara signifikan pada anak asma ringan dan sedang. Th17 merupakan sel $\mathrm{T}$ yang berfungsi memproduksi IL-17a, IL-17b beserta IL-6. Dengan meningkatnya sel Treg yang merupakan sel immunoregulator menginduksi penurunan sel Th17. Adanya penurunan sel Th17 maka menurunkan pula produksi IL- $6 .{ }^{6}$

Hasil penelitian ini menunjukkan perbedaan kadar IL-6 yang signifikan pada asma sedang dibandingkan dengan asma ringan antar kelompok pada sebelum maupun sesudah perlakuan. Setelah dilakukan perlakuan didapatkan penurunan kadar IL-6 lebih tinggi pada kelompok yang diberikan terapi standar dan $N$. sativa daripada kelompok yang hanya mendapatkan terapi standar saja meskipun penuruanya tidak berbeda bermakna menurut data statistik.

Tujuan jangka panjang terapi asma adalah pengendalian gejala dan mengurangi risiko, dengan mengurangi beban pada pasien dan risiko terjadinya kekambuhan, kerusakan jalan napas serta efek samping obat.22 Skor ACT merupakan salah satu metode penilaian klinis asma dalam bentuk variabel numerik, skor $\leq 19$ memiliki makna klinis asma tidak terkontrol, sedangkan skor $>19$ bernilai klinis asma terkontrol baik. ${ }^{23}$

Setelah perlakuan selama 8 minggu, perbandingan rerata perubahan skor ACT antara asma ringan terapi standar dan asma ringan terapi standar dengan $N$. sativa didapatkan penurunan berbeda bermakna, demikian juga perbandingan rerata perubahan skor ACT asma sedang terapi standar dan asma sedang terapi standar dengan $N$. sativa didapatkan penurunan meskipun nilainya tidak berbeda bermakna. Dapat dikatakan bahwa terdapat perubahan yang bermakna skor ACT sebelum dan setelah perlakuan pada kelompok pemberian terapi standar dan $N$. sativa. Hal ini berarti bahwa pemberian terapi standar dan $N$. sativa pada anak asma, baik ringan maupun sedang bermanfaat secara klinis, memperbaiki gejala asma.

Pemberian $N$. sativa selama 3 bulan menurunkan gejala asma, frekuensi kekambuhan, mengi dan perbaikan tes fungsi paru. ${ }^{10}$ Studi yang dilakukan Barlianto (2018) pada mencit asma menunjukkan bahwa $N$. sativa menghambat airway remodelling, dan memodulasi respons imun. ${ }^{6}$ Studi yang dilakukan Aziz (2011) mengatakan bahwa $N$. sativa menunjukkan efek imunomodulator dan antiinflamasi, dapat digunakan sebagai alternatif terapi ataupun terapi tambahan pada pemberian kortikosteroid sebagai terapi asma. ${ }^{9}$ Kombinasi imunoterapi dan $N$. sativa menunjukkan efek perbaikan pada skoring asma. ${ }^{24}$ Studi sebelumnya telah banyak menunjukkan bahwa $N$. sativa terbukti memiliki efek antioksidan, antihistamin dan antiinflamasi. Perbaikan klinis pada studi ini dapat disebabkan oleh efek $N$. sativa sebagai antihistamin, antiinflamasi dan imunomodulator pada asma. 25

Penelitian oleh Sumantri dan Muhyi (2015) menunjukkan bahwa pemberian imunoterapi dan $N$. sativa didapatkan skor tes kontrol asma yang lebih baik dibandingkan dengan pemberian imunoterapi saja dan pemberian imunoterapi, $N$. sativa dan probiotik didapatkan skor yang lebih baik lagi. ${ }^{26,27}$ Sementar, penelitian yang dilakukan oleh Barlianto et al., didapatkan hasil bahwa pemberian minyak $N$. sativa dapat memperbaiki gejala klinis dari asma yang dinilai dengan Asthma Control Test. ${ }^{6}$

Pada penelitian ini tidak didapatkan korelasi antara kadar lgE plasma dengan skor ACT pada asma ringan maupun sedang setelah perlakuan. Tidak adanya korelasi juga pada penurunan kadar IL-6 dengan peningkatan skor ACT yang menunjukkan 
bahwa tidak ada hubungan antara IL-6 dengan skor ACT. Hal ini disebabkan karena IL-6 tidak hanya diproduksi oleh sel Th17, tetapi juga disekresikan oleh sel nonleukosit seperti sel endotel, hepatosit, fibroblas, astrosit, sel epitel, alveolar, adiposit, miosit, sejumlah sel ganas serta jaringan dan sel lainnya. Sehingga ketika sel Th17 menurun, IL-6 tetap diproduksi oleh sel yang lain. ${ }^{16}$

Terdapat beberapa kelemahan pada penelitian ini antara lain tidak dilakukan pemeriksaan kadar IL-6 dan IgE pada Broncho Alveolar Lavage (BAL). Zaslona pada penelitianya mengatakan bahwa pemeriksaan BAL yang dilakukan pada tikus dengan asma yang diberikan Chlorodonat didapatkan penuruan total serum $\lg \mathrm{E}, \lg \mathrm{G} 1$, dan OVA-spesifik $\lg G 1$ seiring dengan penurunan ekspresi IL-4, IL-5, IL-6 dan TGF$\beta 1 .{ }^{28}$ Pada penelitian ini juga tidak dibedakan individu yang sedang mengalami serangan asma atau saat tidak mengalami serangan, sehingga dapat mempengaruhi kadar $\lg E$ dan IL-6 yang berperan pada saat terjadi inflamasi. Adanya faktor risiko pada setiap sampel yang berbeda berupa paparan alergen, atopi, dan lingkungan, yang sulit dikontrol oleh peneliti sehingga dapat terjadi eksaserbasi dan mempengaruhi hasil kadar IL-6, IgE dan skor ACT saat akhir perlakuan. Kelemahan lainnya yaitu status gizi yang berbeda disebabkan faktor sosio-ekonomi pasien yang tidak sama sehingga mempengaruhi derajat maupun frekuensi serangan asma. Asma merupakan penyakit yang disebabkan dominasi sel Th2. Pematangan sel NK dan tingkat aktivasi pada pasien obesitas dengan asma meningkatkan respons inflamasi Th2 dengan mengatur sekresi IL-4 dan IFN-y. Di sisi lain, radang saluran napas dan respons berlebih jalan nafas dari penderita asma obesitas menunjukkan gejala yang lebih parah dan perubahan patofisiologis daripada asma. ${ }^{29}$

\section{Kesimpulan}

Pemberian $N$. sativa dapat menurunkan kadar IL-6 dan IgE plasma pada anak dengan asma ringan dan sedang serta perbaikan skor Asthma Control Test pada anak dengan asma sedang, meskipun secara statistik nilainya tidak berbeda bermakna, tetapi dapat meningkatkan skor ACT pada asma ringan dengan bermakna. Tidak terdapat hubungan antara penurunan IgE dan IL-6 plasma dengan peningkatan skor Asthma Control Test setelah pemberian $N$. sativa pada anak asma ringan dan sedang.

\section{Daftar Pustaka}

1. Rahajoe $N$, Kartasasmita $C B$, Supriyatno $B$, Setyanto DB (Editor). Pedoman Nasional Asma Anak. Edisi Ke-2. Cetakan Ke-2. UKK Respirologi Ikatan Dokter Anak Indonesia. Jakarta. 2016. HIm.1-80.

2. Riset Kesehatan Dasar. Badan Penelitian dan Pengembangan Kesehatan Kementerian Kesehatan RI. 2013. HIm. 83 $-87$.

3. Yacoub MR, Incorvaia C, Caminati M, Colombo G. Immune Mechanisms of Allergen Specific Immunotherapy. Open Allergy J. 2012; 5(2):47-52.

4. Samitas K, Lötvall J, Bossios A. B Cells: from Early Development to Regulating Allergic Diseases. Arch Immunol Ther Exp. 2010; 58(3):209-225.

5. Park SJ \& Lee YC. Interleukin-17 Regulation: an Attractive Therapeutic Approach for Asthma. Respir Res. 2010; 11(1): 78.doi: 10.1186/1465-9921-11-78.

6. Barlianto W, Wulandari D, Chusniah M, Kusuma HMSC, Prawiro SR. Improvement of Th17/Treg Balance and Asthma Control Test Score by Nigella sativa Supplementation in Asthmatic Children: A New Approach to Managing Asthma. Turk J Immunol. 2018; 6(1):1-7. 
7. Srirangan S, Choy LH. The Role of Interleukin 6 in the Pathophysiology of Rheumatoid Arthritis. Ther $A d v$ Musculoskelet Dis. 2010; 2(5):247-56. doi: 10.1177/1759720X10378372.

8. Jia CE, Zhang HP, Yan L, Liang R, Jiang $Y Q$, Powell $H$, et al. The Asthma Control Test and Asthma Control Questionnaire for Assessing Asthma Control: Systematic Review and Meta-Analysis. J Allergy Clin Immunol. 2013; 131(3):695-703.

9. Aziz AE, Sayed NS, \& Mahran, LG. AntiAsthmatic and Anti-Allergic Effects of Thymoquinone on Experimentally-Induced Hypersensitivity. Egyptian Journal of Basic and Clinical Pharmacology. 2011; 1 (3):1-41.

10. Boskabady MH, Keyhanmanesh R, Khameneh S, Doostdar Y, Khakzad MR. Potential Immunomodulation Effect of The Extract of Nigella sativa on Ovalbumin Sensitized Guinea Pigs. J Zhejiang UnivSci B. 2011; 12(3):201-209. doi: 10.1631/ jzus.B1000163.

11. Deo SS, Mistry KJ, Kakade AM, Niphadkar PV. Relationship of Total IgE, Specific IgE, Skin Test Reactivity and Eosinophils in Indian Patient with Allergy. JIACM. 2010; 11(4):265-271.

12. Fattory $H$, Tri $A E$, Barlianto $W$, Olivianto E, Kusuma HMSC. Efek Imunoterapi, Probiotik, Nigella sativa terhadap Rasio CD4+/CD8+, Kadar lgE, dan Skoring Asma. Jurnal Kedokteran Brawijaya. 2015; 4(28):328-333.

13. Sugiono L, Olivianto E, Nurdiana, Barlianto W, Kusuma HMSC. The Effect of House Dust Mite Immunotherapy, Probiotic and Nigella sativa in the Number of CD4+IL4+ Cell, Total IgE Level and Asthma Control Test (ACT) Score. IOSR Journal. 2013; 7(3):32-39.

14. Lloyd \& Hesel. Functions of $T$ Cells in Asthma: More Than Just $\mathrm{T}(\mathrm{H}) 2$ cells. Nat Ref Immunol. 2010; 10(12):838-48.
15. Kusuma HMSC, Barlianto W, Widodo MA, Suharto S. Crude Extract of Black Seed (Nigella sativa) can Modulate T CD4+ and CD8+ Lymphocytes in Asthmatic Mouse Model. Pediatric Respiratory Review. 2012; 13(1):55-61.

16. Okeny PK, Ongom P, Kituuka O. Serum Interleukin-6 Level as an Early Marker of Injury Severity in Trauma Patients in an Urban Low Income Setting: a Cross Sectional Study. BMC Emerg Med. 2015; 15(22).

17. Rose SJ. IL-6 Trans-Signaling via the Soluble IL-6 Receptor: Importance for the Pro-Inflammatory Activities of IL-6. Int J Biol Sci. 2012; 8(9):1237-1247.

18. Fangwei L, Xinming $X$, Shaojun L, Rui K, Bo Z, Lan $Y$, et al. Interleukin-6 Gene 174G/C Polymorphism and Bronchial Asthma Risk: a Meta-Analysis. Int J Clin Exp Med. Xi'an. 2015; 8(8):12601-12608.

19. Neveu WA, Allard JL, Raymond DM, Bourassa LM, Burns SM, Bunn JY, et al. Elevation of IL-6 in the Allergic Asthmatic Airway is Independent of Inflammation but Associates with Loss of Central Airway Function. Respir Res. 2010; 11(1):28.

20. Koshak A, Yousif NM, Heinrich, Fiebich B, Koshak E. Comparative Immunomodulatory Activity of Nigella sativa L. Preparations on Proinflammatory Mediators: A Focus on Asthma. Frontiers in Pharmacology. 2018; 9(10):33-89.

21. Shahzad M, Yang $X$, Raza $A$, Sun $Q$, Han $Y$, Zhang $F$, et al. Black Seed Oil Ameliorates Allergic Airway Inflammation by Inhibiting T-Cell Proliferation in Rats. Pulmonary Pharmacology \& Therapeutics. 2008; 22(10):37-43.

22. Global Initiative for Asthma (GINA). Pocket Guide for Asthma Management and Prevention. A Pocket Guide For Health Professionals Update 2018. 2018. Pp. 11-15. 
23. Shi Y, Tatavoosian A, Aledia A, George S, \& Galant P. Cut Points for Asthma Control Tests in Mexican Children in Orange Country California. Ann Allergy Asthma Immunol. 2010; 109(1):108-113.

24. Kardani AK, Fitri LE, Barlianto W, Olivianto $E$, and Kusuma HMSC. The Effect of House Dust Mite Immunotherapy, Probiotics and Nigella sativa in the Number of Th17 Cell and Asthma Control Test Score. IOSR journals, 2013; 6:37-47.

25. Majdalawieh \& Fayyad. Immunomodulatory and Anti-Inflammatory Action of Nigella sativa and Thymoquinone: A Comprehensive Review. Int Immuno Pharmacol. 2015; 28(1):295-304.

26. Sumantri DC, Sumarno, Barlianto $W$, Olivianto E, Kusuma HMSC. Perbedaan Skor ACT, CD4+CD25+ Foxp3treg, CD4+ IFN- $\varnothing$ pada Pemberian Imunoterapi, Probiotik, dan Nigella sativa. Jurnal
Kedokteran Brawijaya. 2015; 28(4):283290.

27. Muhyi A, Barlianto W, Kusuma HMSC. Efek Pemberian Imunoterapi, Probiotik, Nigella sativa terhadap Th17, Neutrofil, dan Skoring Asma. Jurnal Kedokteran Brawijaya, 2015; 28(3):334-339.

28. Zaslona Z, Przybranowski S, Wilke C, Rooijen Nv, Tennenbaum ST, Osterholzer $\mathrm{JJ}$, et al. Resident Alveolar Macrophages Suppress whereas Recruited Monocytes Promote Allergic Lung Inflammation in Murine Models of Asthma. Journal of Immunology. 2014; 193(8):4245-53. doi: 10.4049/jimmunol.1400580.

29. Chen YP, Zhang JH, Li CQ, Sun QX, Jiang $\mathrm{XH}$. Obesity Enhances Th2 Inflammatory Response via Natural Killer $T$ cell in a Murine Model of Allergic Asthma. Int J Clin Exp Med. 2015; 8(9): 15403-15412. 